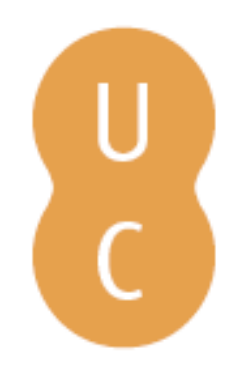

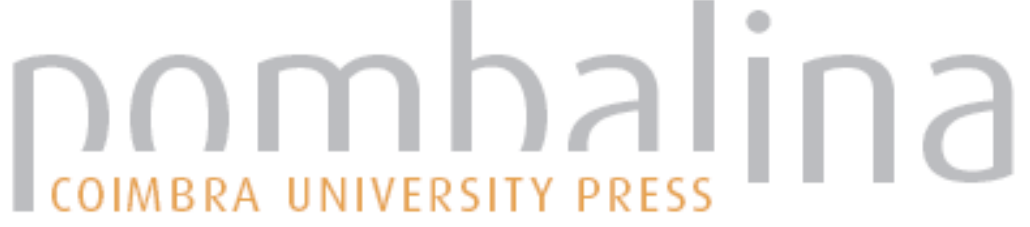

\section{The extreme weather conditions behind the destructive fires of June and October 2017 in Portugal}

Autor(es): $\quad \begin{array}{ll}\text { Pinto, Miguel M.; Hurduc, Alexandra; Trigo, Ricardo M.; Trigo, Isabel F.; } \\ \text { DaCamara, Carlos C. }\end{array}$

Publicado por: Imprensa da Universidade de Coimbra

URL persistente: URI:http://hdl.handle.net/10316.2/44530

DOI: DOl:https://doi.org/10.14195/978-989-26-16-506_13

Accessed : $\quad$ 26-Apr-2023 12:22:09

A navegação consulta e descarregamento dos títulos inseridos nas Bibliotecas Digitais UC Digitalis, UC Pombalina e UC Impactum, pressupõem a aceitação plena e sem reservas dos Termos e Condições de Uso destas Bibliotecas Digitais, disponíveis em https://digitalis.uc.pt/pt-pt/termos.

Conforme exposto nos referidos Termos e Condições de Uso, o descarregamento de títulos de acesso restrito requer uma licença válida de autorização devendo o utilizador aceder ao(s) documento(s) a partir de um endereço de IP da instituição detentora da supramencionada licença.

Ao utilizador é apenas permitido o descarregamento para uso pessoal, pelo que o emprego do(s) título(s) descarregado(s) para outro fim, designadamente comercial, carece de autorização do respetivo autor ou editor da obra.

Na medida em que todas as obras da UC Digitalis se encontram protegidas pelo Código do Direito de Autor e Direitos Conexos e demais legislação aplicável, toda a cópia, parcial ou total, deste documento, nos casos em que é legalmente admitida, deverá conter ou fazer-se acompanhar por este aviso.

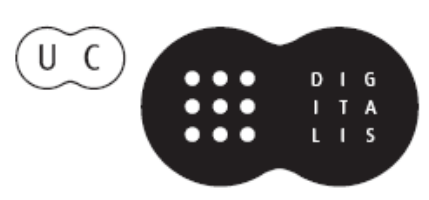




\section{ADVANCES IN}

\section{FOREST FIRE RESEARCH}

\section{8}

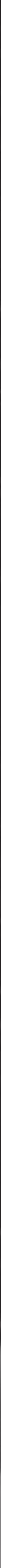




\title{
The extreme weather conditions behind the destructive fires of June and October 2017 in Portugal
}

\author{
Miguel M. Pinto ${ }^{1 *}$; Alexandra Hurduc ${ }^{1}$; Ricardo M. Trigo ${ }^{1}$; Isabel F. Trigo ${ }^{2}$; Carlos C. DaCamara ${ }^{1}$ \\ ${ }^{1}$ Instituto Dom Luiz (IDL), Faculdade de Ciências, Universidade de Lisboa, Lisbon, 1749-016, \\ Portugal. \{mnpinto@fc.ul.pt*; ahurduc@fc.ul.pt; rmtrigo@fc.ul.pt; cdcamara@fc.ul.pt\} \\ ${ }^{2}$ Instituto Português do Mar e da Atmosfera (IPMA), Lisbon, 1749-077, Portugal. \\ \{isabel.trigo@ipma.pt\}
}

\begin{abstract}
The 2017 fire season in Portugal was marked by two tragic events leading to a toll of 116 fatalities and serious impacts at social, economic, and ecological levels. The first of the two events started on June 17 and the second on October 15. With the aim to better understand and predict future similar situations, we conducted an analysis of the meteorological conditions in which the two fire events took place. First, we analyzed the events in a high-resolution meteorological context, using simulations by the Weather Research and Forecasting Model (WRF) and then within a climatic context with resource to ERA-Interim reanalysis. Fire Weather Index (FWI) was used to evaluate the meteorological conditions at the surface level while the Continuous Haines Index (CHI) was employed to assess the atmospheric instability conditions. WRF simulations show high temperature and low relative humidity for both fire events. Conversely, the October 15 event presents strong winds whereas the June 17 event show weak winds at synoptic level. However, for the June event, the model simulates several downburst phenomena, associated with a mesoscale convective system, in agreement with the Doppler radar observations that show several gust fronts associated to the convective system that developed during the evening, reinforcing the need for the $\mathrm{CHI}$ to assess the vertical instability conditions. Monthly climatology of daily FWI and CHI were computed for the period spanning 1979-2016. Results show that for October 15, FWI is the new absolute maximum in the daily time-series, and CHI is at the percentile 90 for the extended fire season (June to September). On the other hand, for June 17, FWI is near the percentile 75 for the extended fire season and CHI is close to the percentile 99 . We conclude that both fire events were associated to extreme meteorological conditions, however their characteristics are very distinct. For the June 17 event the atmospheric instability played a main role in the fast spread of the fire, whereas for the October 15 the strong winds associated with the close passage of hurricane Ophelia, together with extreme drought conditions were the main drivers.
\end{abstract}

Keywords: wildfires, mega-fires, weather models, Fire Weather Index, Continuous Haines Index.

\section{Introduction}

Forest fires are an important characteristic of Mediterranean climate. Portugal is regularly affected by large and destructive wildfires leading to serious impacts at social, economic, and ecological levels (Amraoui et al. 2015). The 2017 fire season was particularly conspicuous in several ways, with a record total burned area of about 500000 hectares and tragic toll of 116 fatalities. Furthermore, the unusual extent of the 2017 fire season implied that the two most tragic events occurred prior (17-20 June) and after (15-17 October) the official fire season window used by the Portuguese authorities.

The case of June was marked by a heat wave that affected western and central Europe leading to very unusual conditions for that month (Sánchez-Benítez et al. 2018). The largest fires in central Portugal (Pedrogão-Grande and Gois) started on June 17, a day characterised by anomalous high temperatures and low relative humidity, associated to very unstable atmospheric conditions that favoured the formation of convective cells and thunderstorms. According to the report from the Portuguese Weather Service (IPMA) this instability, further strengthened by local fires, also led to 
several downburst events and associated gust fronts that played an important role in the fast spread of the fire (Moreira et al. 2017).

The case of October was marked by strong and persistent southerly winds caused by the close passage of hurricane Ophelia moving northward. The winds and the very dry vegetation due to the extreme drought situation were the main ingredients for the tragic events of October 15.

In this study we explore the two events, first in a high-resolution meteorological context using simulations by the Weather Research and Forecasting Model (WRF) initialized with ERA5 reanalysis and running on a grid covering Portugal with a spatial resolution of $4 \mathrm{~km}$ and then within a climatic context with resource to ERA-Interim reanalysis (Dee et al. 2011) for the period 1979-2017. Both ERA-Interim and ERA5 reanalysis are produced by the European Centre for Medium-Range Weather Forecasts (ECMWF), being the ERA5 the most recent state-of-the-art dataset, featuring hourly analysis fields with $0.3^{\circ}$ spatial resolution.

\section{Data and Methods}

This study focuses on the region comprising mainland Portugal paying close attention to the subregion delimited by the green box in Figure 1.

To assess the mesoscale weather conditions, we used WRF version 3.9.1 simulations on a $4 \mathrm{~km}$ spatial resolution grid, covering mainland Portugal, initialized with ERA5 reanalysis data as boundary conditions, with 64 vertical levels.

Meteorological fire danger conditions at the surface level were evaluated using the Fire Weather Index (FWI) that is part of the Canadian Fire Weather Index System (CFFWIS, Van Wagner 1974; Van Wagner 1987) and is a widely used fire danger rating system in Mediterranean Europe (e.g.: San-Miguel-Ayanz et al. 2012; DaCamara et al. 2014; Pinto et al. 2018). This index measures the severity due to the present meteorological conditions but has also a memory from the past conditions based on a measure of fuel moisture. The Continuous Haines Index (CHI) is an extension of a discrete index proposed by Haines (1988) to measure atmospheric instability conditions that may allow for erratic fire behaviour (Mills and McCaw 2010).

The climatology of both FWI and CHI was computed using data from ERA-Interim reanalysis for the period spanning 1979 to 2017. Average FWI values for the defined sub-region are computed using 2 metre temperature and relative humidity, 10 metre wind speed and $24 \mathrm{~h}$ accumulated precipitation all referring to the $12 \mathrm{~h}$ UTC. Average CHI for the subregion are also computed at $12 \mathrm{~h}$ UTC using the temperature in degrees Celsius at 850 and $700 \mathrm{hPa}$ and the dew point temperature at $850 \mathrm{hPa}$ (Mills and McCaw, 2010).

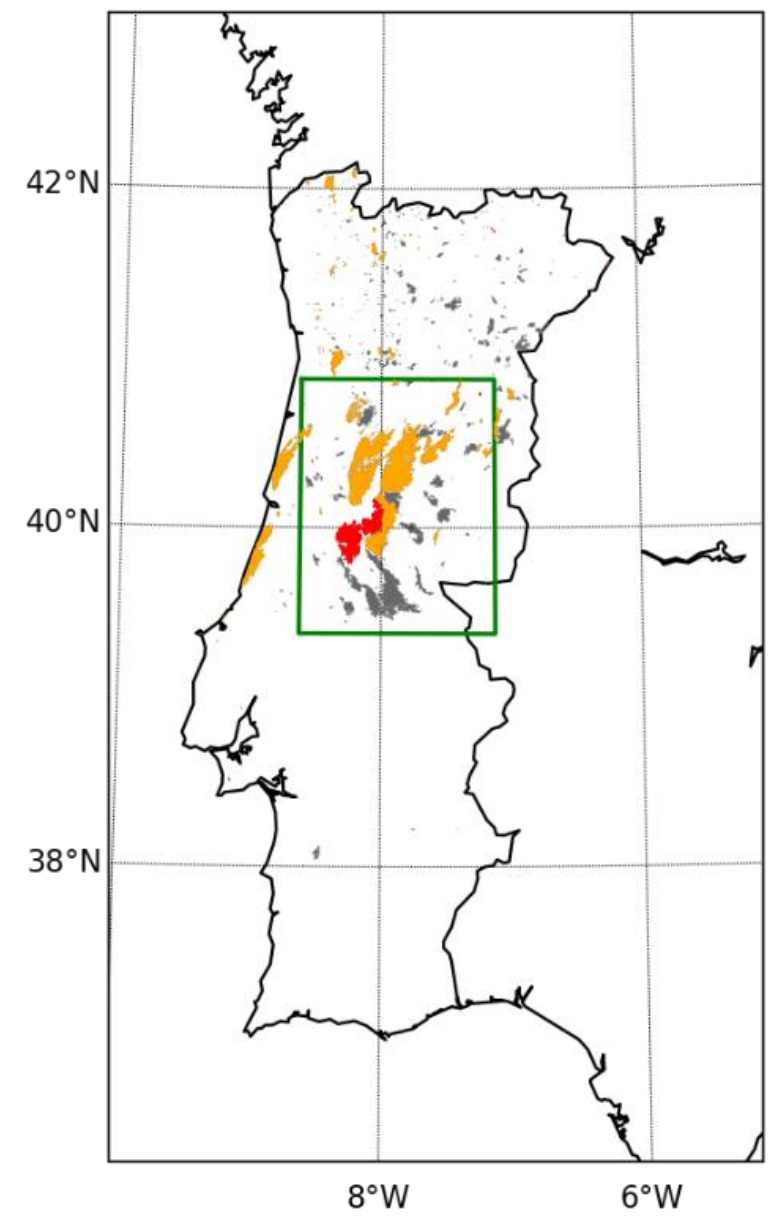

Figure 1 - The map shows the burned areas for 2017 in mainland Portugal for the October case (orange), the June case (red) and the remaining period (gray). The green rectangle delimits the sub-region of study. 
In order to evaluate the sensitivity of FWI to meteorological variables, the average of each input variable is calculated for the respective month during the study period and FWI is then computed replacing each variable by the climatology of the month, one at the time. This allows evaluating how much FWI increases or decreases due to the positive or negative anomalies observed for each variable and to accordingly rank the contribution of each meteorological variable.

\section{Results and discussion}

High-resolution simulations produced by the WRF model at a $4 \mathrm{~km}$ spatial and hourly temporal resolutions allow for a better understanding of mesoscale characteristics that are not neither represented in the coarser grids of reanalyses nor in global circulation models. Figure 2 shows the WRF forecasts for 2 metre temperature, relative humidity and wind speed (left to right panels) valid at 15 UTC of 17 June (top panels) and 15 October, 2017 (bottom panels).

We can see that for June 17 (Fig 2, top panels) values of temperature were very high in most of the region, reaching anomalies of more than $+12^{\circ} \mathrm{C}$ (as marked by black contours) when comparing to the average for June for the period 1979-2017. As for relative humidity, very dry conditions were observed, with values more than $20 \%$ below average over most of the country. For wind speed, the picture is quite distinct, with negative anomalies being observed in most of the study region although the WRF shows several round-shaped regions of strong winds, up to $70 \mathrm{~km} / \mathrm{h}$ at the considered hour. These concentric diverging strong wind regions are consistent with phenomena of downbursts and convective gust fronts that are simulated by the model in association with a convective system (Fujita 1985). Moreover, the location, spatial extent and wind velocity achieved are fairly in agreement with satellite and radar observations that show the development of strong convective storms and the occurrence of multiple convective gust fronts during the afternoon (Moreira et al. 2017). Figure 3 (left panel) presents the average vertical profile for the sub-region of study as simulated by the WRF model at 15 UTC. Dry conditions at the lower atmospheric levels are observed followed by a more humid region that became saturated in places where the convective system developed. Rain or ice droplets falling start to evaporate when passing through the dry region, leading to evaporative cooling that results in downwards acceleration until the air mass reaches the ground and spreads horizontally with strong, sometimes damaging, wind gusts (Fujita 1985).

As shown in the bottom panels of Figure 2, the October 15 event is characterized by high temperatures, with anomalies above $+10^{\circ} \mathrm{C}$ and very low relative humidity values, more than $40 \%$ below average in a large part of central and north Portugal. However, it must be stressed that wind was the main driver of this event. The last panel of Figure 2 shows strong winds with anomalies greater than $10 \mathrm{~km} / \mathrm{h}$. These strong winds with southerly orientation were mainly caused by the nearby passage of hurricane Ophelia which was centred at about $485 \mathrm{~km}$ from Viana do Castelo $\left(41.7^{\circ} \mathrm{N}, 8.82^{\circ} \mathrm{W}\right)$ on the considered day (IPMA, 2017). As shown in Figure 3 a dry region at the lower layers of the atmosphere is present in both June and October cases, superimposed by a more humid layer (at about $500 \mathrm{hPa}$ ), the main difference being the presence of a drier layer above $400 \mathrm{hPa}$ in the October event. It is also important to notice that, in October, besides the strong wind, the ongoing extreme drought conditions were a major key ingredient for the unprecedented dimension of burned area observed in Portugal in a single day. 

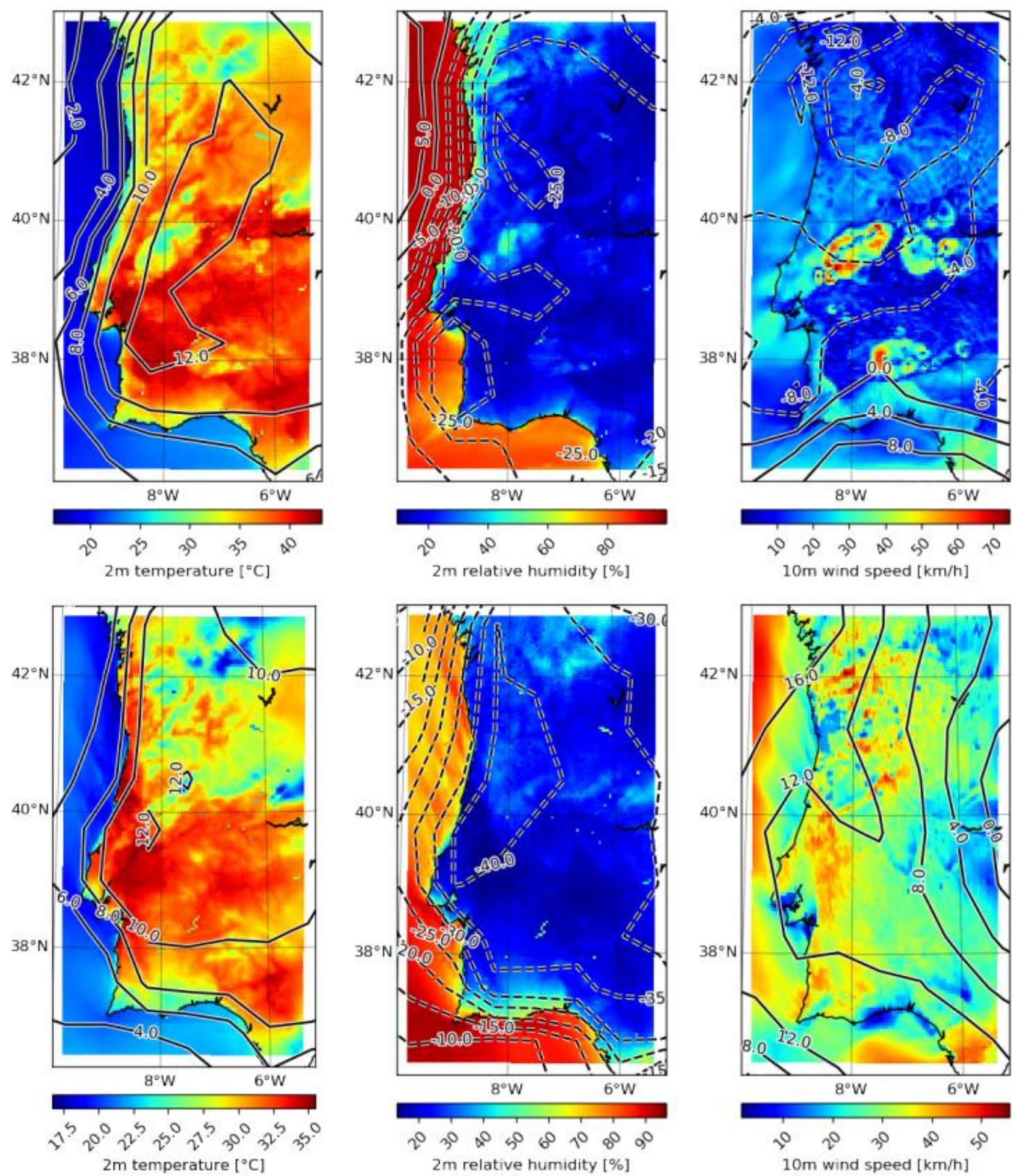

Figure 2-15 UTC fields of 2-metre temperature and relative humidity and of wind speed (left to right panels) as simulated by the WRF model for June 17 (top panels) and October 15, 2017 (bottom panels). Fields are coloured according to the respective colour bars and black contours represent ERA-Interim anomalies, with dashed lines indicating negative anomalies. 

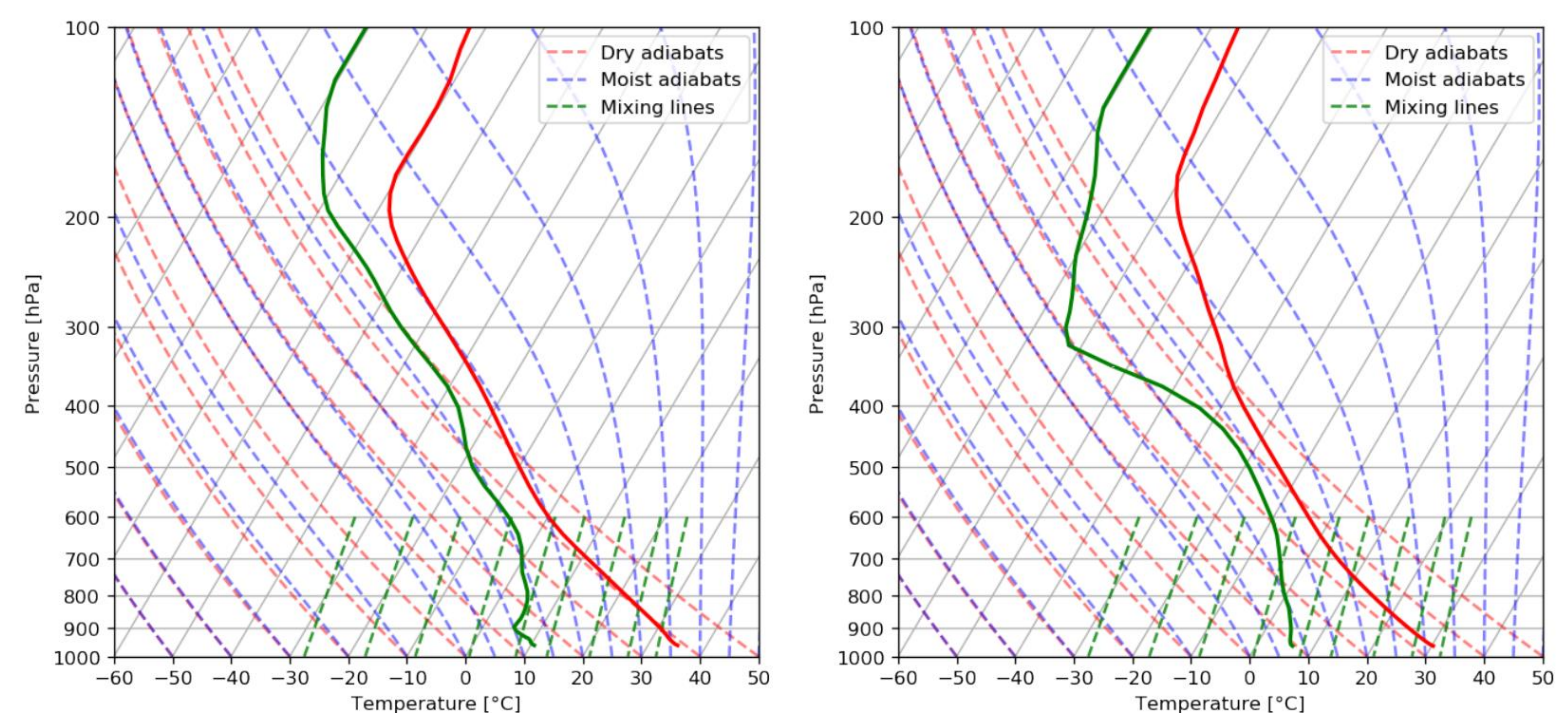

Figure 3 - Vertical profiles of temperature (red line) and dew point temperature (green line) in ${ }^{\circ} \mathrm{C}$, as simulated by the WRF model, at 15 UTC of June 17 (left panel) and October 15 (right panel). Dashed red, blue and green lines respectively represent the dry adiabats, moist adiabats and saturating mixing ratio.

It is also worth mentioning that while the October case is very well characterized by means of largescale conditions, in the case of June, high resolution information provided by the mesoscale model is fundamental to resolving the mesoscale convective storms and better understand the situation. This predisposition of the atmosphere for instability conditions can be measured by CHI (Mills and McCaw 2010). For that we computed both CHI and FWI for each day since 1979 using ERA-Interim reanalysis data. Results (Figure 4) show that the October case was indeed an absolute extreme in FWI while the June case was characterised by values above percentile 75 for the month of June and just below percentile 75 when considering the extended fire season (from June to September). However, when looking for CHI we see that the June case shows a CHI above 10, very close to percentile 99 for the extended fire season, while the October case corresponds to percentile 90 . This reinforces the idea that looking to the vertical instability conditions provides additional information that is necessary in order to obtain a more in-depth characterization of the extreme event at the local to regional scales. Moreover, instability indices such as $\mathrm{CHI}$ that are fairly simple to compute can be used for a more complete information about fire danger. According to Mills and McCaw (2010), values of CHI above 10 imply an extremely difficult setting to extinguish fires and a high risk of under-predicted behaviour. This is in agreement with the observations for June 17 where fast fire spread was observed with the development of pyrocumulonimbus (Moreira et al. 2017).
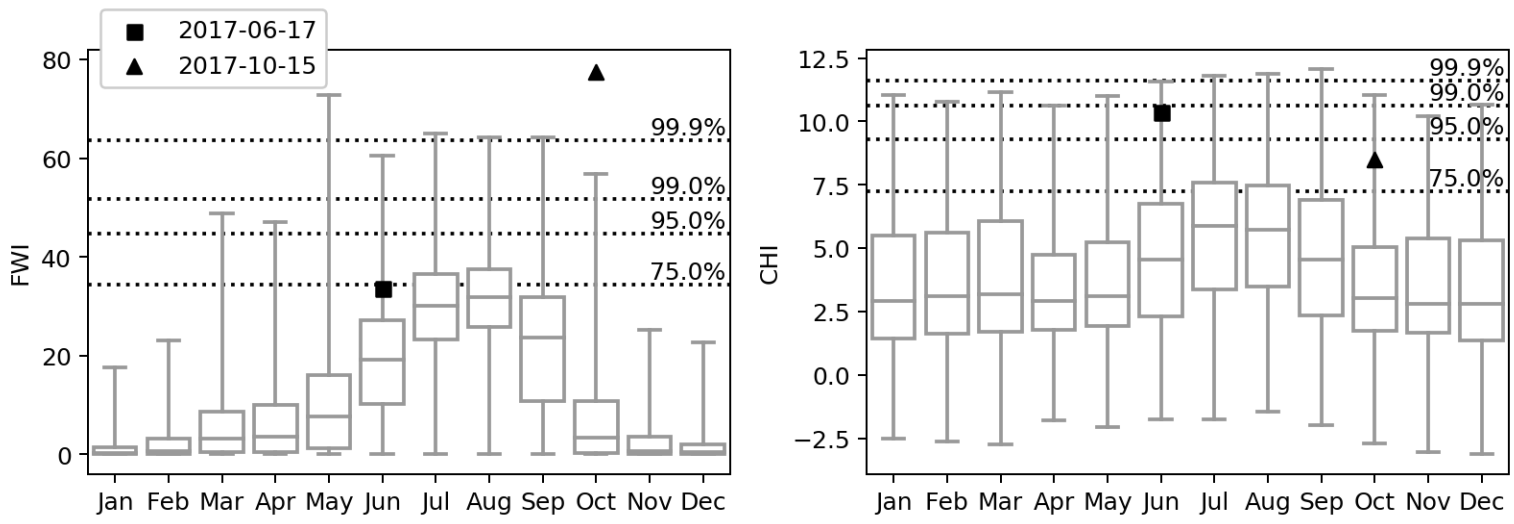

Figure 4-Boxplots of monthly distributions of FWI (left panel) and CHI (right panel) for the period 1979-2016). The horizontal dashed lines indicate percentiles for the extended fire season (June to September) whereas the black squares and triangles refer to the values for June 17 and October 15, 2017. 
Table 1 presents a comparison of values of FWI for June 17 and October 15 with values of the same index computed with temperature, relative humidity, and wind intensity, respectively replaced by the respective monthly means over the period 1979-2017.

Considering the case of June 17, when replacing the wind speed by the climatological mean there is a small increase of $3 \%$ of FWI (from 34 to 35) whereas decreases of $18 \%$ and 24\%, (from 34 to 28 and from 34 to 26) are obtained when replacing temperature and relative humidity by climatological means. This is to be expected, since the large-scale wind speed is below average whereas the other two variables are above average (Figure 2). Relative humidity was accordingly the most important factor contributing to the observed value of FWI, closely followed by temperature. However as discussed earlier, the mesoscale wind associated with the convective system has played a main role that is not captured by FWI at such coarse scale and the effect is better quantified by $\mathrm{CHI}$.

Table 1: FWI observed and modelled (replacing observed temperature, wind and relative humidity by respective monthly means in 1979-2017) for June 17 and October 15, 2017. In brackets, the relative change (\%) of each modelled value from the respective observed value.

\begin{tabular}{|c|c|c|c|}
\hline & \multicolumn{2}{|c|}{ FWI } \\
\hline & & 17 Jun & $15 \mathrm{Oct}$ \\
\hline \multicolumn{2}{|r|}{ Observed } & 34 & 78 \\
\hline \multirow{3}{*}{$\overline{\bar{g}} \overline{\mathrm{g}}$} & Wind & $35[+3 \%]$ & $41[-47 \%]$ \\
\hline & Temperature & $28[-18 \%]$ & $66[-15 \%]$ \\
\hline & Relative humidity & $26[-24 \%]$ & $46[-41 \%]$ \\
\hline
\end{tabular}

Analysing the case of October 15, it may be noted that FWI reached a value of 78 (more than double of June 17). In this case all parameters present a positive contribution. The most notorious change occurs when considering the average wind speed, followed by the relative humidity. When modelling FWI replacing wind speed by the monthly average for October, the resulting FWI value drops to 41, almost half of the observed value. The contribution of relative humidity closely follows that of wind whereas temperature has the smallest contribution.

\section{Conclusions}

Analysis of FWI and CHI in a climate context shows that both June and October fire events were associated to extreme meteorological conditions. However, the characteristics of these two events are very distinct. The June event happened very early in the fire season in a context of a heat wave and a very unstable atmosphere that allowed for a fast and unpredictable spread of the fires. The October case, in turn, took place late in the fire season in a situation of extreme drought and in a day marked by strong winds associated with the close passage of hurricane Ophelia that led to a very fast fire spread.

A closer look at the sensitivity of FWI to meteorological conditions shows that for the June 17 case temperature and relative humidity were the main contributors, the large-scale wind speed being below average. For the October 15 case, all meteorological variables considered show a positive contribution. Wind speed and relative humidity were the most relevant contributing variables that led to a record FWI value of 78 for the considered region, indicating an extreme potential fire intensity associated with a high rate of fire spread due to the strong winds.

It is also shown that the WRF model initialized with boundary conditions given by state-of-the-art reanalyses, in this case ERA5, can reasonably well simulate the development of the convective systems and the atmospheric instability. Furthermore, the incorporation of $\mathrm{CHI}$ as a measure of atmospheric 
instability can represent an added value when rating fire danger, a topic that is currently being addressed in our research.

\section{Acknowledgments}

Research by Miguel M. Pinto was supported by the Portuguese Science Foundation (FCT) through $\mathrm{PhD}$ grant PD/BD/142779/2018. Research by Alexandra Hurduc was supported by a grant in the framework of Project "Reabilitação das Áreas Queimadas na Freguesia de Alvares", financed by donation of Observador on time SA.

\section{References}

Amraoui M, Pereira MG, DaCamara, CC, Calado TJ (2015) Atmospheric conditions associated with extreme fire activity in the Western Mediterranean region. Science of the Total Environment 524, 32-39.

DaCamara CC, Calado TJ, Ermida SL, Trigo IF, Amraoui M, Turkman KF (2014) Calibration of the Fire Weather Index over Mediterranean Europe based on fire activity retrieved from MSG satellite imagery. International Journal of Wildland Fire 23(7), 945-958.

Dee DP, Uppala SM, Simmons AJ, Berrisford P, Poli P, Kobayashi S, Andrae U, Balmaseda MA, Balsamo G, Bauer P, Bechtold P, Beljaars ACM, van de Berg L, Bidlot J, Bormann N, Delson C, Dragani R, Fuentes M, Geer AJ, Haimberger L, Healy SB, Hersbach H, Hólm EV, Isaksen L, Kallberg P, Köhler M, Matricardi M, McNally AP, Monge-Sanz BM, Morcrette J-J, Park B-K, Peubey C, de Rosnay P, Tavolato C, Thépaut J-N, Vitart F (2011) The ERA-Interim reanalysis: Configuration and performance of the data assimilation system. Quarterly Journal of the Royal Meteorological Society 137, 553-597.

Fujita TT (1985) The Downburst: Microburst and Macroburst. SMRP Research Paper 210, 112.

Haines DA (1988) A lower atmosphere severity index for wildlife fires. National Weather Digest 13, 23-27.

IPMA (2017) Boletim Climatológico outubro 2017 Portugal continental. Instituto Português do Mar e da Atmosfera. (Lisbon)

Mills GA, McCaw WL (2010) Atmospheric stability environments and fire weather in Australia extending the Haines Index. Centre for Australian Weather and Climate Research Technical Report number 20. (Melbourne)

Moreira N, Silva A, Novo I, Rio J, Pinto P, Correia S, Barbosa S, Cota T (2017) Condições meteorológicas associadas ao incêndio de Pedrógão Grande de 17 junho 2017. Instituto Português do Mar e da Atmosfera. (Lisbon)

Pinto MM, DaCamara CC, Trigo IF, Trigo RM, Turkman KF (2018) Fire danger rating over Mediterranean Europe based on fire radiative power derived from Meteosat. Natural Hazards and Earth System Sciences 18(2), 515-529.

San-Miguel-Ayanz J, Schulte E, Schmuck G, Camia A, Strobl P, Liberta G, Giovando C, Boca R, Sedano F, Kempeneers P, McInerney D, Withmore C, Oliveira SS, Rodrigues M, Durrant T, Corti P, Oehler F, Vilar L, Amatulli G (2012) Comprehensive Monitoring of Wildfires in Europe: The European Forest Fire Information System (EFFIS). In 'Approaches to Managing Disaster Assessing Hazards, Emergencies and Disaster Impacts'. (Ed. J Tiefenbacher) (InTech: Croatia)

Sánchez-Benítez A, García-Herrera R, Barriopedro D, Sousa PM, Trigo RM (2018) June 2017: The Earliest European Summer Mega-heatwave of Reanalysis Period. Geophysical Research Letters 45(4), 1955-1962. 
Van Wagner CE (1974) Structure of the Canadian Forest Fire Weather Index. Canadian Department of Environment. Canadian Forestry Service, Publication 1333. (Ottawa, ON)

Van Wagner CE (1987) The development and structure of the Canadian Forest Fire Weather Index System. Canadian Forest Service, Petawawa National Forestry Institute, Forestry Technical Report FTR-35. (Chalk River, ON) 